\title{
Influence of climate on Pelorus Sound mussel aquaculture yields: predictive models and underlying mechanisms
}

\author{
J. R. Zeldis ${ }^{1,2, *}$, M. G. Hadfield ${ }^{3}$, D. J. Booker ${ }^{1}$ \\ ${ }^{1}$ National Institute of Water and Atmospheric Research Ltd., 10 Kyle St., PO Box 8602, Riccarton 8011, Christchurch, \\ New Zealand \\ ${ }^{2}$ Joint Graduate School in Coastal and Marine Science, University of Auckland, 12 Grafton Rd, Auckland 1010, New Zealand \\ ${ }^{3}$ National Institute of Water and Atmospheric Research Ltd, 301 Evans Bay Parade, Greta Point, Wellington 6022, \\ New Zealand
}

\begin{abstract}
Multiple regression models were used to predict aquaculture production in Pelorus Sound, a $50 \mathrm{~km}$ long estuary supporting $68 \%$ of New Zealand's greenshell mussel Perna canaliculus aquaculture industry (worth NZ\$ 204 million per annum). Mussel meat yield was modelled using both biological predictors, including seston (indexed by particulate nitrogen, PN), phytoplankton and nutrients collected over 9 yr (July 1997 to November 2005) by the mussel industry, and physical, climatic predictors, including Southern Oscillation Index (SOI), along-shelf winds, sea surface temperature (SST) and Pelorus River flow, held in New Zealand national databases. Yield was best predicted using biological predictors collected locally at the farms inside the sound, but it was also predictable using only physical predictors collected distant from the farming region. Seston (mussel food) was also predictable using the physical predictors. Optimal predictor sets for yield and seston differed between summer and winter half-years. In summer, deep water (which enters the sound through the estuarine circulation) at the sound entrance was nitrate $\left(\mathrm{NO}_{3}{ }^{-}\right)$-rich during upwelling conditions (negative SOI, NNW wind stress and cool SST). The increased $\mathrm{NO}_{3}{ }^{-}$levels, in turn, triggered increased PN within the sound. In the winter half-year, PN was unrelated to upwelling and $\mathrm{NO}_{3}{ }^{-}$effects at the entrance and was instead related to river flow. Remotely-sensed SST data showed that in summer, upwelling affected the entrance waters of the sound under negative SOI and upwelling-favourable wind stress, patterns which dissipated in winter. Overall, these results show that time series of physical drivers can be useful for explaining production variation of farmed bivalves and indicate the prospects for using data routinely collected in national databases for predicting mussel yield.
\end{abstract}

KEY WORDS: Bivalve $\cdot$ Prediction $\cdot$ ENSO $\cdot$ Upwelling $\cdot$ River flow $\cdot$ Estuaries $\cdot$ Phytoplankton Seston

\section{INTRODUCTION}

Predicting the biological yield of aquaculture is important to the industry carrying out the farming. Planning stocking rates on the basis of predicted growing conditions, or predicting the longevity or return periods of poor growing conditions, requires

*Email: j.zeldis@niwa.co.nz understanding of the drivers of secondary production of the aquaculture system. Mussel aquaculture relies on suspended seston supply for its nutrition (Figueiras et al. 2002), so it can be expected that variability in seston supply will affect farming success. Seston, in turn, is formed via primary production and is composed of living and detrital material (Verity 2002b),

(C) The authors 2013. Open Access under Creative Commons by Attribution Licence. Use, distribution and reproduction are unrestricted. Authors and original publication must be credited. 
so it is reasonable to expect that environmental drivers of primary production will have flow-on effects on seston abundance and bivalve aquaculture performance (Nixon \& Buckley 2002). Such linkages mean that if predictive models and understanding of the drivers of seston abundance can be developed, plausible models for predicting mussel yield may follow.

In spite of the importance of developing such predictive capability, relationships between environmental variation and bivalve aquaculture yield have rarely been demonstrated (Kremer et al. 2000). The teleconnections of large-scale climatic drivers, for example between basin-scale El Niño Southern Oscillation (ENSO) dynamics (McPhaden et al. 2006) and local atmospheric and oceanic effects, can be subtle. The way they combine to drive conditions conducive to primary and secondary production within coastal marine ecosystems can be complex and variable (e.g. Monbet 1992, Cloern 2001, Bar- bosa et al. 2010, Friedland et al. 2012). Overall, processes must be observed across wide time and space scales, to understand their relationships. Large sets of appropriate environmental data (atmospheric, hydrometric and oceanic) are needed, along with aquaculture production information, set against a background of local ecosystem understanding (e.g. Alvarez-Salgado et al. 2008, Barbosa et al. 2010). Such requirements appear to have made predictive models of bivalve aquaculture yield relatively rare.

In considering mussel production in Pelorus Sound, New Zealand (Fig. 1), Zeldis et al. (2008) examined correlations among physical, chemical and biological variables and variation in mussel aquaculture yield. This large estuary supports ca. $68 \%$ of the NZ\$204 million per annum, 75000 t fresh weight, national production of New Zealand greenshell Perna canaliculus mussels, which are grown on hundreds of individual farms throughout its main channel,

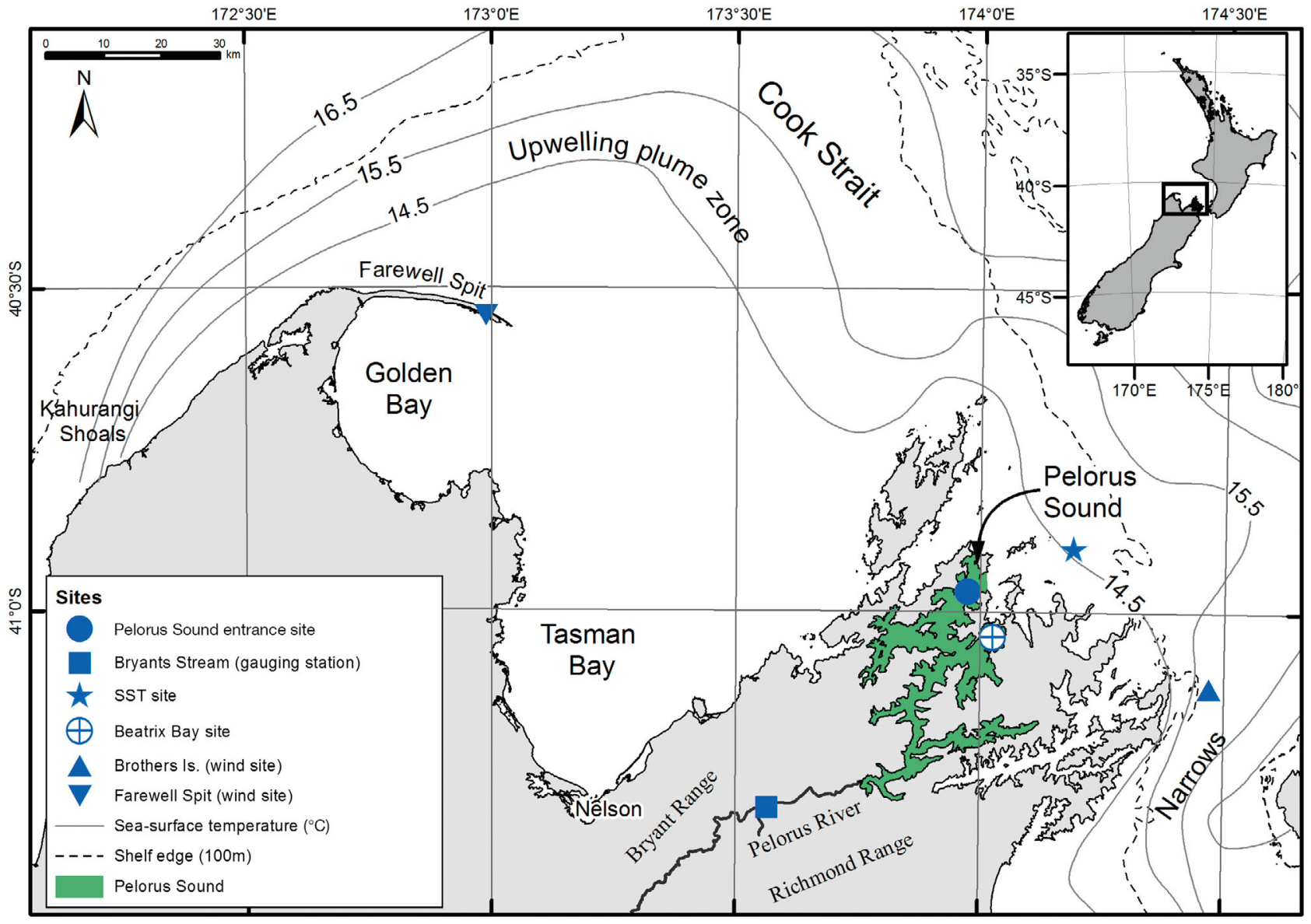

Fig. 1. Central New Zealand: northern South Island (rectangle), including Pelorus Sound (green). Isotherms in Cook Strait show location of upwelling-affected waters in western Cook Strait (from ship survey data collected in summer [JanuaryFebruary] 1980, summarized by Harris 1990). Also shown are western Cook Strait continental shelf (100 m isobath), sampling sites in Pelorus Sound (Beatrix Bay) and at Pelorus entrance, the location of sea surface temperature (SST) data collection, the Brothers Island and Farewell Spit wind gauging stations and the Pelorus River (Bryant's Stream) river flow gauging station 
side-arms and embayments (New Zealand Marine Farming Association: www.nzmfa.co.nz/industryinfo. asp). Starting in early 1999, farm production in the sound declined by ca. $25 \%$ (measured in terms of per capita meat yield), followed by recovery through 2002, resulting in substantial economic impacts and distortions within the industry (Hayden et al. 2000). Similar fluctuations have been observed again in more recent, anecdotal accounts (2007-2008: S. Preece in Marlborough Express of 6 May 2008). Major environmental and economic incentives thus underscored the need to understand the drivers of mussel production in Pelorus Sound.

In disentangling the drivers of mussel yield in this ecosystem, Zeldis et al. (2008) showed that overgrazing by mussels (i.e. top-down effects: Prins et al. 1998, Ogilvie et al. 2000, Møhlenberg et al. 2007, Huang et al. 2008) could not explain the 1999-2002 yield minimum. Instead, bottom-up effects of oceanic and river nitrogen $(\mathrm{N})$ supply were proposed as drivers of the variation in mussel yield, consistent with other studies demonstrating relationships of marine secondary production with $\mathrm{N}$ supply (reviewed by Nixon \& Buckley 2002). Zeldis et al. (2008) correlated the yields with physical environmental variables (e.g. ENSO, sea surface temperature [SST], along-shelf wind stress and river flow) and chemical and biological variables (e.g. nitrate $\left[\mathrm{NO}_{3}{ }^{-}\right]$, phytoplankton and particulate nitrogen [PN], as a proxy for seston). However, the relationships were not quantified within a predictive model, nor were the underlying biophysical mechanisms of $\mathrm{NO}_{3}{ }^{-}$and sestonic food supply in Pelorus Sound well understood.

Here, we present new analyses which quantify the relationships of drivers of mussel yield and seston in the sound, using multiple regression models which include effects of physical 'distal' variables (i.e. those measured distant from the farming region), and more 'local' chemical and biological variables measured in the farming region within the sound. Specifically, the models were used to test 3 hypotheses: (1) that variations in mussel yield can be predicted using observed variations in the large-scale, distal physical variables; (2) that variations in mussel yield can be better predicted from observed variations in local chemical and biological conditions than from largescale, distal physical conditions; and (3) that the seston food supply for mussels can be successfully predicted using distal variables.

We then explain the predictions of the regression models with investigations of the underlying mechanisms of Pelorus Sound seston and mussel yield variation. Nitrate data collected at the entrance to the sound where it joins Cook Strait (Fig. 1) were analysed to describe relationships of seston abundance within the sound with 'new' $\mathrm{NO}_{3}{ }^{-}$fluxes from Cook Strait and from the Pelorus River. At larger scales, we examined teleconnections of macro-scale forcing with mesoscale upwelling dynamics affecting $\mathrm{NO}_{3}{ }^{-}$supply at the sound entrance, using spatial correlations of SST, wind and Southern Oscillation Index (SOI) data, to describe linkages of central New Zealand oceanography with seston biomass variation within the sound. Via our 3 hypotheses, a key question we answer is whether seston abundance and aquaculture yield within Pelorus Sound can be predicted using only the distal physical variables which are routinely available in national databases, or if it is necessary to use local chemical or biological data collected within the farming region.

\section{MATERIALS AND METHODS}

\section{Environmental setting}

Pelorus Sound is a relatively deep (40 m average), narrow, highly indented drowned valley estuary about $56 \mathrm{~km}$ long at the north end of New Zealand's South Island (Fig. 1). Riverine input, dominated by the Pelorus River, and estuarine exchanges with Cook Strait both affect the dynamics of the sound (Bradford et al. 1987, Gibbs et al. 1992, Dupra 2000) with seasonally varying influence (Zeldis et al. 2008). Pelorus River flow rates average 18 and $22 \mathrm{~m}^{3} \mathrm{~s}^{-1}$ and $\mathrm{NO}_{3}{ }^{-}$ concentrations average 140 and $170 \mathrm{mg} \mathrm{N} \mathrm{m}^{-3}$ in summer and winter, respectively (Shearer 1989), such that winter river $\mathrm{NO}_{3}{ }^{-}$loads are twice those of summer. River inputs also affect vertical density stratification in the sound, influencing interactions between light and nutrient environments of phytoplankton (Gibbs \& Vant 1997, Strayer et al. 2008, Barbosa et al. 2010).

Oceanic effects on the sound are also seasonal. The sound entrance is affected by upwelled waters advected there from the Kahurangi Shoals upwelling zone at the western approaches of the Strait (Harris 1990; our Fig. 1). The upwelling is driven by winds from the west (Harris 1990, Shirtcliffe et al. 1990) and is potentially enhanced during El Niño summers, when the negative SOI state correlates with westerly winds over New Zealand (Gordon 1986, Mullan 1998). This correlation weakens in spring/autumn and disappears completely in winter, when negative SOI correlates with winds from the SW and S, respectively (Gordon 1986, B. Mullan pers. comm.). 


\section{Data sources and analyses}

SOI data (based on Tahiti and Darwin air pressures) were obtained from January 1979 to May 2009 (Australian Bureau of Meteorology, www.bom.gov. au/climate). Wind velocities were obtained from Brothers Island (Agent 4395) adjacent to Pelorus Sound entrance and at Farewell Spit (Agent 3798: Fig. 1) in NW Cook Strait for the same period (NIWA National Climate Centre). The continental shelf edge adjacent to Brothers Island has an approximate NNW-SSE orientation $\left(330^{\circ}-150^{\circ}\right.$; Fig. 1), so alongshelf $(v)$ components of the winds were calculated with the wind bearings rotated to orient them with the local bathymetry, by resolving the wind vector along $-30^{\circ}\left(\mathrm{V}\right.$ positive toward $\left.330^{\circ}\right)$. Wind stress was calculated as in Sharples \& Greig (1998). Note that in the convention applied here, negative values correspond to wind stress blowing from the NNW and positive values indicate stress blowing from the SSE. Wind stresses at Farewell Spit were extracted on the $\mathrm{W}-\mathrm{E}\left(270^{\circ}-90^{\circ}\right)$ bearing corresponding to the orientation of the shelf occurring at that location (Fig. 1), with wind stress toward $90^{\circ}$ being negative and toward $270^{\circ}$ positive. Major and minor wind axes were calculated by the methods of Preisendorfer \& Mobley (1988) to describe the mean wind variability at the 2 locations. Monthly mean SST was obtained using AVHRR satellite radiometer data (NIWA SST Archive, NSA: Uddstrom \& Oien 1999) over the greater Cook Strait region for January 1993 to May 2009 at $5 \mathrm{~km}^{2}$ resolution. Monthly averaged sea-surface wind stress anomalies (Brothers Island or Farewell Spit) and SOI were correlated with SST at each $5 \mathrm{~km}^{2}$ pixel location over the greater Cook Strait region from January 1993 (start of the NSA archive) to May 2009. To monitor temperatures specifically at the entrance to the sound, averaged data from a 3-by-3 pixel array centred on $40.90^{\circ} \mathrm{S}, 174.19^{\circ} \mathrm{E}$, were used (Fig. 1). Pelorus River flows gauged at Bryant's Stream (Fig. 1) were obtained from the NIWA Climate Centre from January 1979 to May 2009 and were analysed using the methods of McKerchar (2002).

Samples collected weekly for assessing chemical $\left(\mathrm{NO}_{3}{ }^{-}\right.$; ammonium, $\mathrm{NH}_{4}{ }^{+} ; \mathrm{PN}$; and particulate carbon, PC) and biological (chlorophyll $a$, chl $a_{\text {; }}$ and diatom and dinoflagellate taxon carbon) variables were obtained from Marlborough Shellfish Quality Programme (MSQP) monitoring and analysed as described by Zeldis et al. (2008). Total microphytoplankton carbon biomass was calculated as the sum of these taxa and accounted for an average of $71 \%$ of total phytoplankton carbon (Safi \& Gibbs 2003).
These variates were obtained in Beatrix Bay (midPelorus Sound: Fig. 1) for the period July 1997 to May 2009. Data on per capita meat yield of mussels were obtained from Sealord Shellfisheries for 11378 mussel farm long-lines harvested in Pelorus Sound from July 1997 until November 2005 (the end of their data availability). Upon harvest, a sample of 20 mussels from each line was weighed whole, then cooked, shelled and the meat re-weighed, on board the harvesting vessel. Weekly-collected $\mathrm{NO}_{3}{ }^{-}$and $\mathrm{PN}$ samples from the MSQP station at the entrance to the sound (Fig. 1) were obtained at $40 \mathrm{~m}$ depth for the period February 2002 to May 2009 (the start and end dates of their collection period) using a Van Dorn closing bottle and analysed according to Zeldis et al. (2008).

Monthly anomalies of SST, wind stress, river flow, chemical and biological variates and mussel yield were obtained by calculating the mean for each variate for every month in its respective time series, and then subtracting from it the mean for each month over the entire time series.

\section{Regression modelling and correlations}

Based on prior knowledge, the seasonality of environmental drivers of the sound (see 'Environmental setting', above) we split the data for our regression models and correlations into 2 sets, representing summer (October through March) and winter (April through September) half-years, with 50 and 48 monthly observations in each, respectively. Table 1 defines the variables used and describes the models used to test our 3 hypotheses. We applied lags of 1 mo between measurement times of biological and physical anomalies to account for the timescale of Pelorus Sound water mass turnover (ca. 20 d; Heath 1976, Dupra 2000) and phytoplankton growth re-

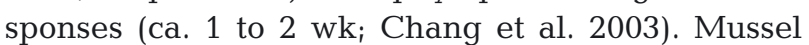
yield anomalies were lagged by 1 mo with respect to biological anomalies and by 2 mo with respect to physical anomalies to account for the response of mussel yield to variable food supply and its physical forcing, respectively (Ren \& Ross 2005). Data from July 1997 to September 2005 (the time span of the mussel yield data coincident with the lagged physical data) were used in the regression modelling.

The aims of our modelling were to assess links between local and distal predictor variables (see 'Introduction') and the response variables mussel yield and PN (index of seston), where local variables were chemical and biological data derived from 
Table 1. (a) Regression model parameter definitions and (b) model descriptions for predictions of anomalies of mussel yield and particulate nitrogen (PN) concentrations in winter and summer half-years

\begin{tabular}{|c|c|c|c|c|}
\hline $\begin{array}{l}\text { (a) } \\
\text { Variable name }\end{array}$ & \multicolumn{3}{|c|}{ Variable definition } & Unit \\
\hline SOI & & \multicolumn{2}{|l|}{ Southern Oscillation Index } & - \\
\hline Wind & & \multicolumn{2}{|c|}{ Along-shelf wind-stress anomaly (positive from SSE) } & $\mathrm{Pa}$ \\
\hline SST & & \multicolumn{2}{|c|}{ Sea surface temperature anomaly } & ${ }^{\circ} \mathrm{C}$ \\
\hline Flow & & \multicolumn{2}{|c|}{ Pelorus River flow anomaly } & $\mathrm{m}^{-3} \mathrm{~s}^{-1}$ \\
\hline Nit & & \multicolumn{2}{|c|}{ Nitrate concentration anomaly } & $\mathrm{mg} \mathrm{N} \mathrm{m}^{-3}$ \\
\hline PN & & \multicolumn{2}{|c|}{ Particulate nitrogen concentration anomaly } & $\mathrm{mg} \mathrm{N} \mathrm{m}^{-3}$ \\
\hline $\mathrm{Chl}$ & & \multicolumn{2}{|c|}{ Chlorophyll anomaly } & $\mathrm{mg} \mathrm{m}^{-3}$ \\
\hline Diat & & \multicolumn{2}{|l|}{ Diatom carbon anomaly } & $\mathrm{mg} \mathrm{C} \mathrm{m}^{-3}$ \\
\hline Phy C & & \multicolumn{2}{|c|}{ Total microphytoplankton carbon anomaly } & $\mathrm{mg} \mathrm{C} \mathrm{m} \mathrm{m}^{-3}$ \\
\hline Yield & & \multicolumn{2}{|c|}{ Average yield of mussels in Pelorus Sound anomaly } & $\%$ \\
\hline \multicolumn{5}{|l|}{ (b) } \\
\hline Model type & Predictand & Predictors & \multicolumn{2}{|c|}{ Model description } \\
\hline Distal & Yield & SOI, Wind, SST, Flow & \multicolumn{2}{|c|}{ Predicts yield as a function of physical ('distal') drivers } \\
\hline Local & Yield & PN, Diat, Nit, Chl, Phy C & \multicolumn{2}{|c|}{$\begin{array}{l}\text { Predicts yield as a function of chemical and biological } \\
\text { ('local') drivers }\end{array}$} \\
\hline Distal & $\mathrm{PN}$ & SOI, Wind, SST, Flow & \multicolumn{2}{|c|}{ Predicts PN as a function of physical ('distal') drivers } \\
\hline Mean & Yield, PN & $\mathrm{Na}$ & \multicolumn{2}{|c|}{ Predicts the mean of the observed yields or PN } \\
\hline
\end{tabular}

water samples collected proximal to the mussel farms (in mid-Pelorus Sound at Beatrix Bay) and distal variables were physical data observed remote from the farming locations which were routinely available from national meteorological, hydrometric and remote sensing databases. The predictor variables (Table 1a) for each of these models were chosen specifically to test our 3 hypotheses (Table $1 \mathrm{~b}$ ). In order to nullify the effect of co-variation within the predictor sets, we did not include dissolved inorganic nitrogen (DIN), $\mathrm{PC}$ or dinoflagellate $\mathrm{C}$ anomalies as predictors in our models because they were highly correlated (Pearson correlation coefficients $>0.7$ ) with $\mathrm{NO}_{3}{ }^{-}$, PN and phytoplankton $\mathrm{C}$ anomalies, respectively. Ciliates are filtered by Perna canaliculus (Zeldis et al. 2004) and were enumerated in the MSQP data. However, their $\mathrm{N}$-specific variation was only 4 to $5 \%$ of PN variation in summer and winter, respectively (data not shown) and so was not considered in the regression modelling.

All models were fitted to the data using linear regression and included 2-way interactions between all predictors. Standard forwards and backwards stepwise linear regression was applied to each model to identify the minimal adequate model from all possible terms included in each model. Therefore, not all available terms (Table 1b) were necessarily included in each model. The Akaike information criterion (AIC; Akaike 1973) was used to apply a penalised log likelihood method to evaluate the trade-off between degrees of freedom and fit of the model as explana- tory parameters were added or removed (Crawley 2002). As selecting terms on the basis of AIC alone has been shown to be somewhat liberal in its choice of terms, a value of $k=4$ was used for the multiple of the number of degrees of freedom used for the penalty in the stepwise procedure (Venables \& Ripley 2002). Mean models, in which each predicted value is the mean of all observed values (Table $1 \mathrm{~b}$ ), were devised to provide null explanation models, for comparisons with our regression models. All model analyses were performed using ' $\mathrm{R}$ ' software (R Development Core Team 2012).

A jackknife cross-validation procedure (Efron 1982) was used to provide an independent test of each regression model. This cross-validation procedure was applied by leaving out all data associated with each observation and then predicting the leftout observation using all remaining observations. For each model of each response in each season, scatterplots of observed against jackknife predicted values were plotted and overlaid with a linear regression with observed values on the $y$-axis as recommended by Piñeiro et al. (2008). We also calculated the rootmean-square-deviance (RMSD):

$$
\mathrm{RMSD}=\sqrt{\left(\sum_{i=1}^{\mathrm{n}} \frac{\left(y_{\text {obs }}-y_{\text {pred }}\right)^{2}}{\mathrm{n}}\right)}
$$

where $y_{\text {obs }}$ and $y_{\text {pred }}$ are the observed and predicted yield, respectively, and $\mathrm{n}$ is the number of observations. RMSD represents a measure of the overall dif- 
ference between observed and estimated yield and PN anomalies for each model. We then tested for significant differences between mean absolute error calculated from each of our jackknifed models in comparison to the appropriate Mean model using analysis of variance (ANOVA). This allowed testing of the null hypothesis that errors for each model were not significantly different to the corresponding mean model. When assessing the significance of these ANOVAs, we relaxed the conventional alpha value of 0.05 to 0.1 . There were several reasons for this relaxation: (1) the observed data were a small subsample of the true population and therefore have associated uncertainties; (2) there are unquantified uncertainties associated with the observed values due to measurement errors as well as the predicted values due to prediction errors; (3) we used a jackknife procedure to provide a more stringent test than would have been the case had fitted values been used; and (4) our models are designed to aid the mussel industry based on balance of probabilities; we therefore accepted an increased probability of rejecting the null hypothesis when it was in fact true (increased Type I errors).

Pearson correlations between physical anomalies (SOI, wind and SST) were made using data from January 1993 to May 2009 (197 values) and between physical anomalies and $\mathrm{NO}_{3}{ }^{-}$and $\mathrm{PN}$ collected at the sound entrance from February 2002 to May 2009 (88 values), both split nearly equally between half-years. Parametric analysis was used, as Shapiro-Wilks tests showed normal variate distributions. No time lags were applied to the $\mathrm{NO}_{3}{ }^{-}$anomalies in this analysis because the Pelorus Sound entrance is close to Cook Strait where the wind and SST anomalies were measured.

\section{RESULTS}

\section{Regression modelling of mussel yield and seston biomass}

The stepwise reduction procedure provided particular formulations that minimised AIC and therefore represented the best trade-off between model complexity and explanatory power for both the distal and local predictors in both summer and winter. The minimally adequate distal and local models revealed several significant predictors (Table 2). Probability (based on RMSDs) that mean absolute errors calculated from jackknifed distal model predictions of yield were the same as those from the mean model
Table 2. Multiple regression models predicting mussel yield anomalies within Pelorus Sound as functions of distal and local predictors for the summer half-year and the winter halfyear ( $\mathrm{n}=50$ mo for each half-year). Note that positive wind stress is from the SSE, and negative wind stress is from the NNW. Variables as in Table $1 .{ }^{* * *} p<0.001,{ }^{* *} p \geq 0.001$ to $<0.01,{ }^{*} p \geq 0.01$ to 0.10

\begin{tabular}{|c|c|c|c|c|}
\hline Predictor & Coefficient & $\mathrm{SE}$ & $t$ & $\mathrm{p}$ \\
\hline \multicolumn{5}{|c|}{ Distal: yield in summer } \\
\hline Constant & -0.331 & 0.954 & -0.347 & 0.731 \\
\hline SOI & -0.198 & 0.086 & -2.294 & $0.027^{*}$ \\
\hline Wind & -23.035 & 9.876 & -2.333 & $0.025^{*}$ \\
\hline Flow & 0.002 & 0.051 & 0.046 & 0.963 \\
\hline SOI: Wind & 1.399 & 0.698 & 2.005 & $0.051^{*}$ \\
\hline Wind: Flow & -0.908 & 0.389 & -2.332 & $0.025^{*}$ \\
\hline \multicolumn{5}{|c|}{ DistaL: yield in winter } \\
\hline Constant & 1.837 & 1.318 & 1.394 & 0.170 \\
\hline SST & -9.693 & 2.747 & -3.528 & $0.001^{* * *}$ \\
\hline Flow & 0.195 & 0.075 & 2.586 & $0.013^{*}$ \\
\hline \multicolumn{5}{|c|}{ Local: yield in summer } \\
\hline Constant & 0.800 & 0.809 & 0.989 & 0.328 \\
\hline $\mathrm{PN}$ & 0.174 & 0.041 & 4.273 & $0.000^{* * *}$ \\
\hline Diat & 0.224 & 0.050 & 4.471 & $0.000^{* * *}$ \\
\hline \multicolumn{5}{|c|}{ Local: yield in winter } \\
\hline Constant & 1.508 & 1.090 & 1.383 & 0.173 \\
\hline PN & 0.381 & 0.066 & 5.763 & $0.000^{* * *}$ \\
\hline
\end{tabular}

was $p=0.077$, and that from the analogous local model was $p=0.003$. This was evidence to support our first hypothesis that variations in monthly mussel yield can be predicted using observed variations in large-scale, physical drivers. Comparison of time series, scatterplots and regression statistics of observed values against jackknife-predicted yield anomalies indicated that the distal models explained less variation in yield than the local models (Fig. 2a-f). This was evidence to support our second hypothesis that variations in monthly mussel yield can be better predicted from observed variations in local biological conditions than from observed variations in largescale physical drivers.

Each model showed seasonal structures of the drivers. In summer, the optimal distal model predictors of increased yields were negative SOI, NW wind stress and interactions among SOI, wind stress and river flow, and optimal local model predictors were increased PN and diatoms. In winter, the optimal distal model predictors of increased yields were cool SST and increased river flow, and the optimal local model predictor was increased PN. Given the seasonal division of the drivers of mussel yield and the importance of PN (our index of seston, or mussel food) in predict- 


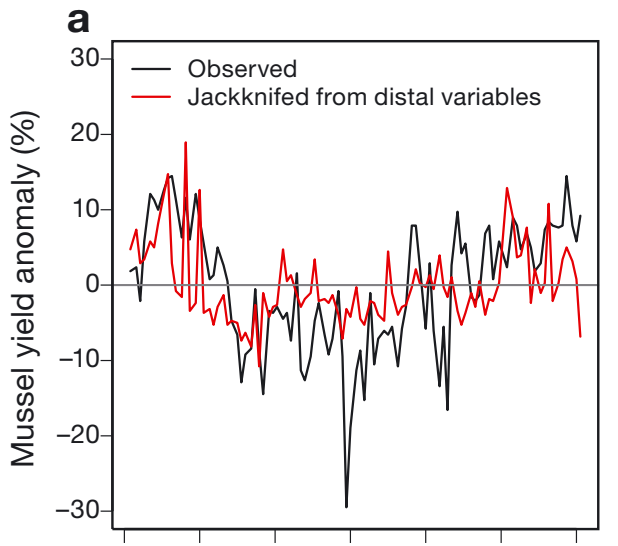

May 1997 Feb 2000 Nov 2002 Aug 2005 Date

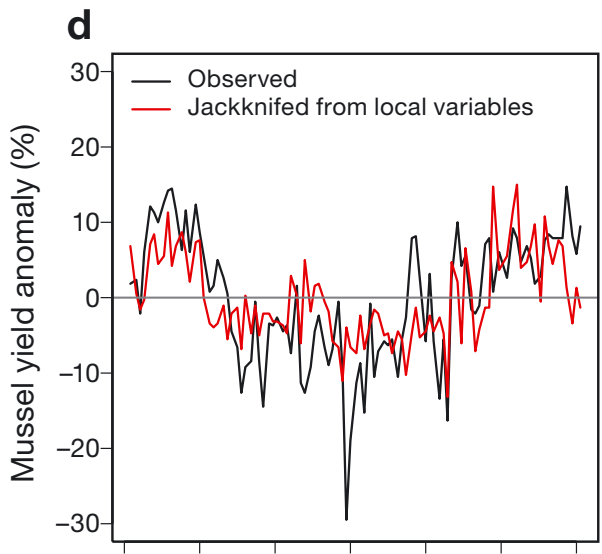

May 1997 Feb 2000 Nov 2002 Aug 2005 Date

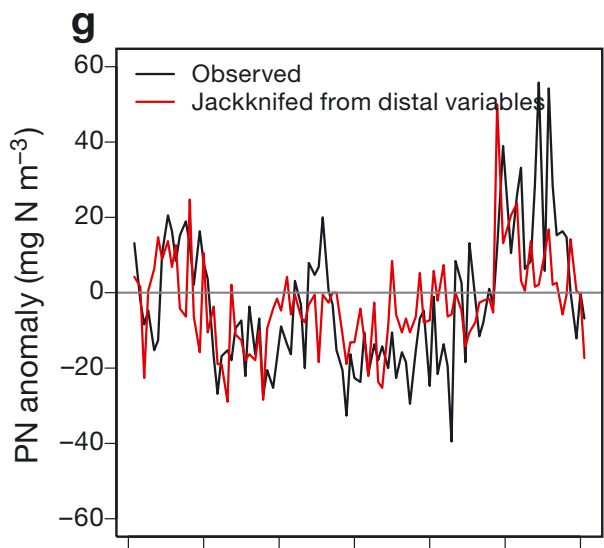

May 1997 Feb 2000 Nov 2002 Aug 2005 Date

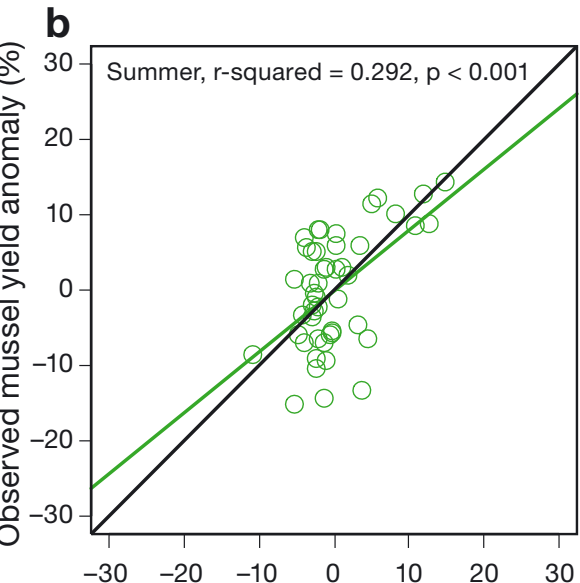

Jackknifed mussel yield anomaly from distal variables (\%)

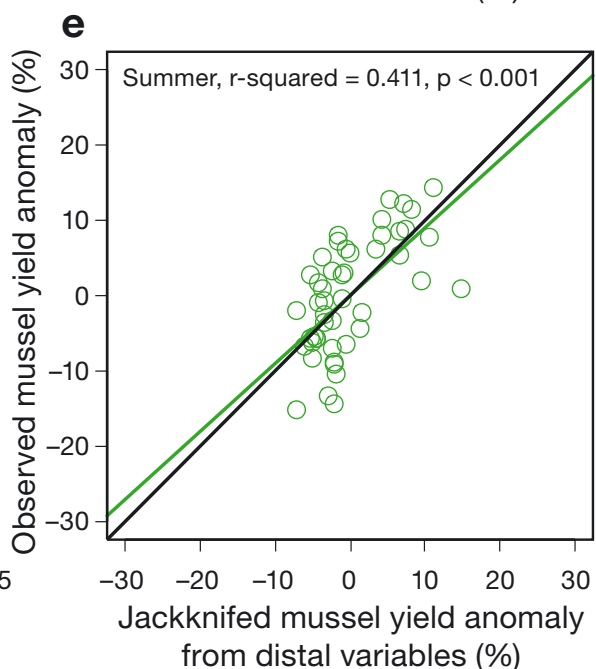

h

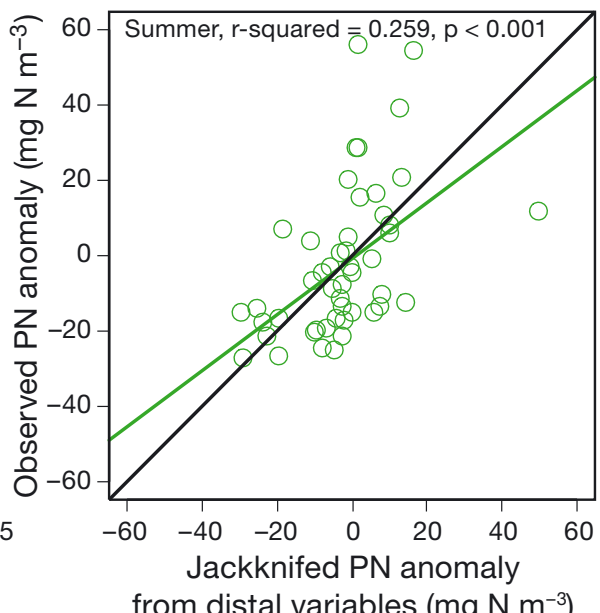

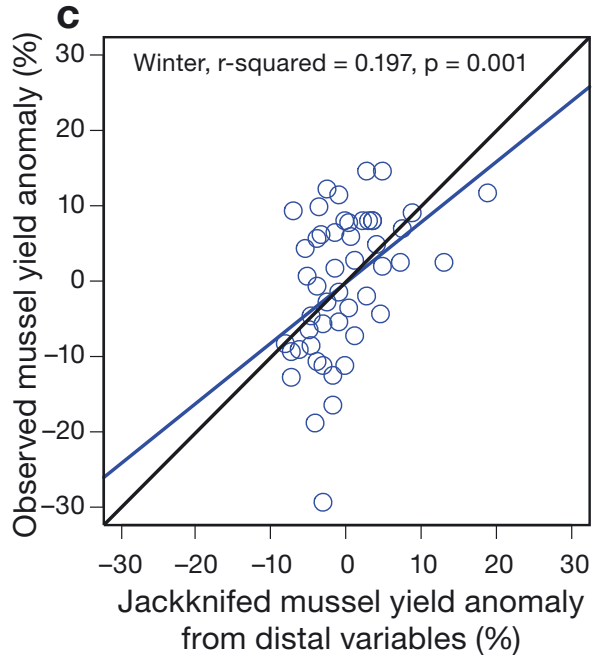

f

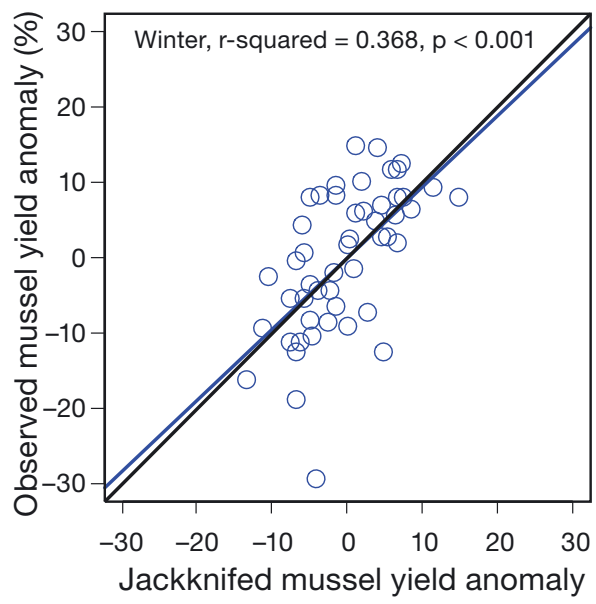

from distal variables (\%)

\section{i}

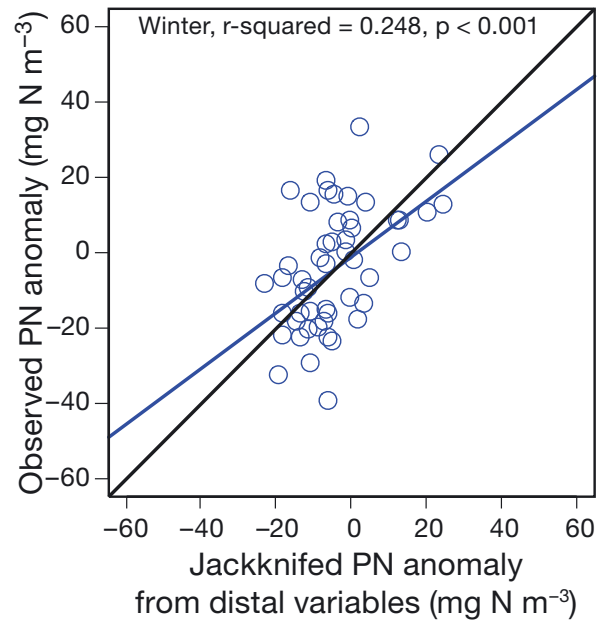

Fig. 2. (a) Time series of monthly mussel yield anomalies (as \% of absolute value of yield) predicted by distal physical predictors (calculated using coefficients in Table 2), plotted with observed yield anomalies. (b, c) Jackknife-predicted values in summer (green) and winter (blue), with fitted linear regression lines; black line is $x=y$. (d-f) Same as above but for yields predicted using local chemical and biological predictors. (e-g) Same as above but for particulate nitrogen (PN) anomalies predicted by distal physical predictors 
ing mussel yield (Table 2), it was not surprising that the distal model of PN also showed seasonal division of its drivers (Table 3). The set of distal predictors of increased PN in summer included NW wind stress, cool SST, increased river flow and an interaction of SST and river flow. The predictors of increased PN in winter were cool SST, increased river flow and an interaction of SOI and wind stress. Overall, the predictors reproduced the time series of observed PN (Fig. $2 g-i$ ), and there was a probability of 0.078 that the mean absolute errors calculated from jackknifed distal model predictions of PN were the same as those from the mean model. This was evidence to support our third hypothesis that the sestonic food supply for mussels can be successfully predicted using distal variables.

While the predictions suggested that distal and local variables were significant drivers of variation of mussel yield and their sestonic food (PN) in the sound, the mechanisms by which they could do so were not explained. This is the subject of the following sections.

\section{Correlations between $\mathrm{NO}_{3}{ }^{-}$dynamics outside and inside Pelorus Sound}

In the summer half-year, anomalies of $\mathrm{NO}_{3}{ }^{-}$measured at $40 \mathrm{~m}$ depth in the entrance to the sound (Fig. 1) correlated negatively with anomalies of SOI, SST and along-shelf wind stress (Table 4), such that

Table 3. Multiple regression models predicting particulate nitrogen (PN) anomalies within Pelorus Sound (Beatrix Bay) as a function of distal predictors for the summer half-year ( $\mathrm{n}=50$ months) and winter half-year ( $\mathrm{n}=48$ months). Note that positive wind stress is from the SSE, and negative wind stress is from the NNW. Variables as in Table $1 .{ }^{* * *} \mathrm{p}<0.001$, ${ }^{* *} p \geq 0.001$ to $<0.01,{ }^{*} p \geq 0.01$ to 0.10

\begin{tabular}{|c|c|c|c|c|}
\hline Coefficient & Estimate & $\mathrm{SE}$ & $t$ & $\mathrm{p}$ \\
\hline \multicolumn{5}{|c|}{ Distal: PN in summer } \\
\hline Constant & 2.917 & 2.730 & 1.069 & 0.291 \\
\hline Wind & -47.274 & 24.242 & -1.950 & $0.058^{*}$ \\
\hline SST & -15.718 & 5.526 & -2.844 & $0.007^{* *}$ \\
\hline Flow & 0.457 & 0.215 & 2.125 & $0.039^{*}$ \\
\hline SST: Flow & -0.888 & 0.410 & -2.163 & $0.036^{*}$ \\
\hline \multicolumn{5}{|c|}{ Distal: PN in winter } \\
\hline Constant & 0.437 & 2.343 & 0.187 & 0.853 \\
\hline SOI & 0.115 & 0.228 & 0.503 & 0.618 \\
\hline Wind & 32.681 & 32.673 & 1.000 & 0.323 \\
\hline $\mathrm{SST}$ & -19.611 & 4.804 & -4.082 & $0.000^{* * *}$ \\
\hline Flow & 0.470 & 0.155 & 3.032 & $0.004^{* *}$ \\
\hline SOI: Wind & 6.337 & 2.856 & 2.219 & $0.032^{*}$ \\
\hline
\end{tabular}

$\mathrm{NO}_{3}{ }^{-}$increased under conditions of El Niño, cool SST and increased wind stress from the NNW. In the winter half-year, $\mathrm{NO}_{3}{ }^{-}$at $40 \mathrm{~m}$ depth at the sound entrance was not correlated with SOI or wind stress, but increased under cool SST. Nitrate at $40 \mathrm{~m}$ was positively correlated with PN sampled within the sound (in Beatrix Bay) in the summer half-year (Fig. 3a) but not in winter (Fig. 3b). We found no significant relationship between anomalies of $\mathrm{PN}$ at $40 \mathrm{~m}$ in the entrance waters and PN within the sound, in either summer $(p=0.27, n=38)$ or winter $(p=0.80$, $\mathrm{n}=37$; data not shown).

Concentrations of $\mathrm{NO}_{3}{ }^{-}$at $40 \mathrm{~m}$ in the sound entrance and $\mathrm{PN}$ within the sound diverged in the winters of 2005 and 2007 (arrows in Fig. 3c), when entrance $\mathrm{NO}_{3}{ }^{-}$concentration was high and withinsound PN was low. These were the 2 driest winters in the entire 30 yr record of flow measurements on the Pelorus River (see annotated river flows in Fig. 3c). Cases when entrance $\mathrm{NO}_{3}{ }^{-}$was low and withinsound PN was high occurred in the winters of 2004 and 2008, when above-average river flows occurred. These patterns were consistent with the significant relationships of river flow with $\mathrm{PN}$ in the multiple regression modelling (Table 3 ) in winter.

Our regression modelling and correlations thus showed that in summer there were significant relationships between upwelling-related physical variables measured outside the sound, on mussel yield (Table 2), PN in the sound (Table 3), and $\mathrm{NO}_{3}{ }^{-}$concentration in the oceanic end-member waters of the

Table 4. Correlations of the Southern Oscillation Index (SOI), anomalies of along-shelf wind stress at Brothers Island and Farewell Spit, sea surface temperature (SST) at Pelorus Sound entrance and $\mathrm{NO}_{3}{ }^{-}$measured in Pelorus Sound entrance at $40 \mathrm{~m}$ depth (Fig. 1) for summer and winter halfyears. For Brothers Island winds, positive (negative) wind stress is from the SSE (NNW); for Farewell Spit winds, positive (negative) wind stress is from the $\mathrm{E}$ (W). Pearson productmoment coefficients are shown; ${ }^{* *} p<0.01,{ }^{*} p=0.01$ to 0.05

\begin{tabular}{|lccc|}
\hline Parameter & Wind, Brothers & $\mathrm{SST}$ & $\mathrm{NO}_{3}{ }^{-}$ \\
\hline Summer & & & \\
SOI & $0.25^{*}$ & $0.34^{* *}$ & $-0.39^{* *}$ \\
Wind, Brothers & - & $0.25^{*}$ & $-0.46^{* *}$ \\
Wind, Farewell & $0.71^{* *}$ & $0.54^{* *}$ & $-0.33^{*}$ \\
SST & - & - & $-0.44^{* *}$ \\
& & & \\
Winter & & & \\
SOI & 0.03 & $0.35^{* *}$ & -0.17 \\
Wind, Brothers & - & -0.07 & -0.15 \\
Wind, Farewell & $0.49^{* *}$ & 0.11 & -0.08 \\
SST & - & - & $-0.56^{* *}$ \\
\hline
\end{tabular}



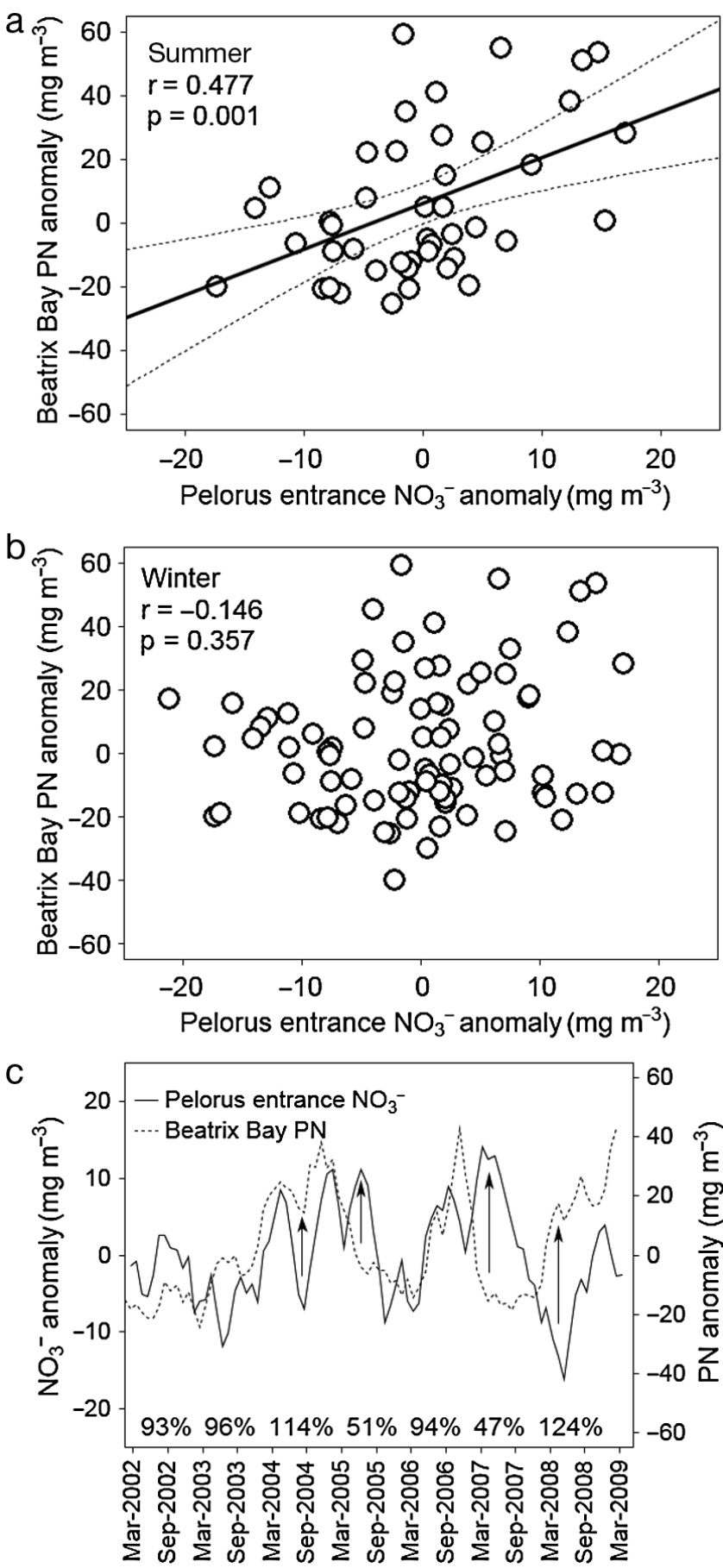

Fig. 3. Nitrate anomalies at Pelorus Sound entrance at $40 \mathrm{~m}$ depth plotted against particulate nitrogen (PN) anomalies within the sound (Beatrix Bay) in (a) the summer half-year (with least-squares fit, 95\% confidence interval) and (b) the winter half-year, respectively. (c) Nitrate anomalies at the sound entrance at $40 \mathrm{~m}$ depth (solid line) and PN anomalies sampled within the sound (dashed line) over 2002 to 2009. Arrows indicate periods of divergence of the $\mathrm{NO}_{3}{ }^{-}$and $\mathrm{PN}$ time series (see 'Results'). Percentages are winter half-year mean river flows, as percentages of mean winter flows over the whole 30 yr Pelorus River flow record sound (Table 4), but that these relationships disappeared in winter. We next use wind stress, SOI and spatially-resolved remotely-sensed SST time series to explain these relationships.

\section{Spatial correlations in Cook Strait}

At Brothers Island adjacent to the entrance of Pelorus Sound (Fig. 1), winds are most often oriented in NNW and SSE directions (Fig. 4a), while at Farewell Spit at the western approaches to Cook Strait they are most often oriented closer to due west and east (Fig. 4b). Both orientations are close to parallel with shelf bathymetry at their respective locations (Fig. 1). Correlations of monthly anomalies of wind stresses at Brothers Island with SST over the region in the summer half-year (Fig. 5a) showed a zone of highest positive correlation near Kahurangi Shoals (Fig. 1) west of Farewell Spit, such that increased stress from the NNW (i.e. negative) had a strong association with cool water at that location. The zone of relatively high correlation ( $r=0.45$ to 0.25 ) extended into western Cook Strait, and included the sound entrance (consistent with the positive summer wind-SST correlation $[r=0.25]$ at the entrance; Table 4). In the winter halfyear (Fig. 5b), the wind-SST correlation at the upwelling zone dissipated and much lower correlations occurred over the entire region (consistent with the non-significant winter wind-SST correlation $[\mathrm{r}=$ -0.07 ] at the sound entrance; Table 4).

For winds measured at Farewell Spit, the correlations with Cook Strait SST in summer were high $(\mathrm{r}=$ 0.60) at Kahurangi Shoals (Fig. 5c), such that westerly (negative) wind stress was strongly associated with cool water. The high-correlation zone $(r=0.60$ to 0.50 ) extended throughout the western strait including all of Golden and Tasman Bays and the entrance waters of Pelorus Sound (Table 4). As for Brothers Island winds, in winter the correlation weakened considerably, halving in the Kahurangi Shoals area (Fig. 5d) and western strait and essentially disappearing throughout the rest of the strait including the sound entrance.

In summary, westerly wind stress measured at Farewell Spit was well correlated with cool water at the entrance of Pelorus Sound, in summer. These winds were steered toward the SSE nearer the sound entrance where they correlated with entrance SST. In winter, these upwelling-related patterns of correlation were absent or muted.

Similar to the summer spatial correlations of wind stress and SST, the summer spatial correlation of SOI 

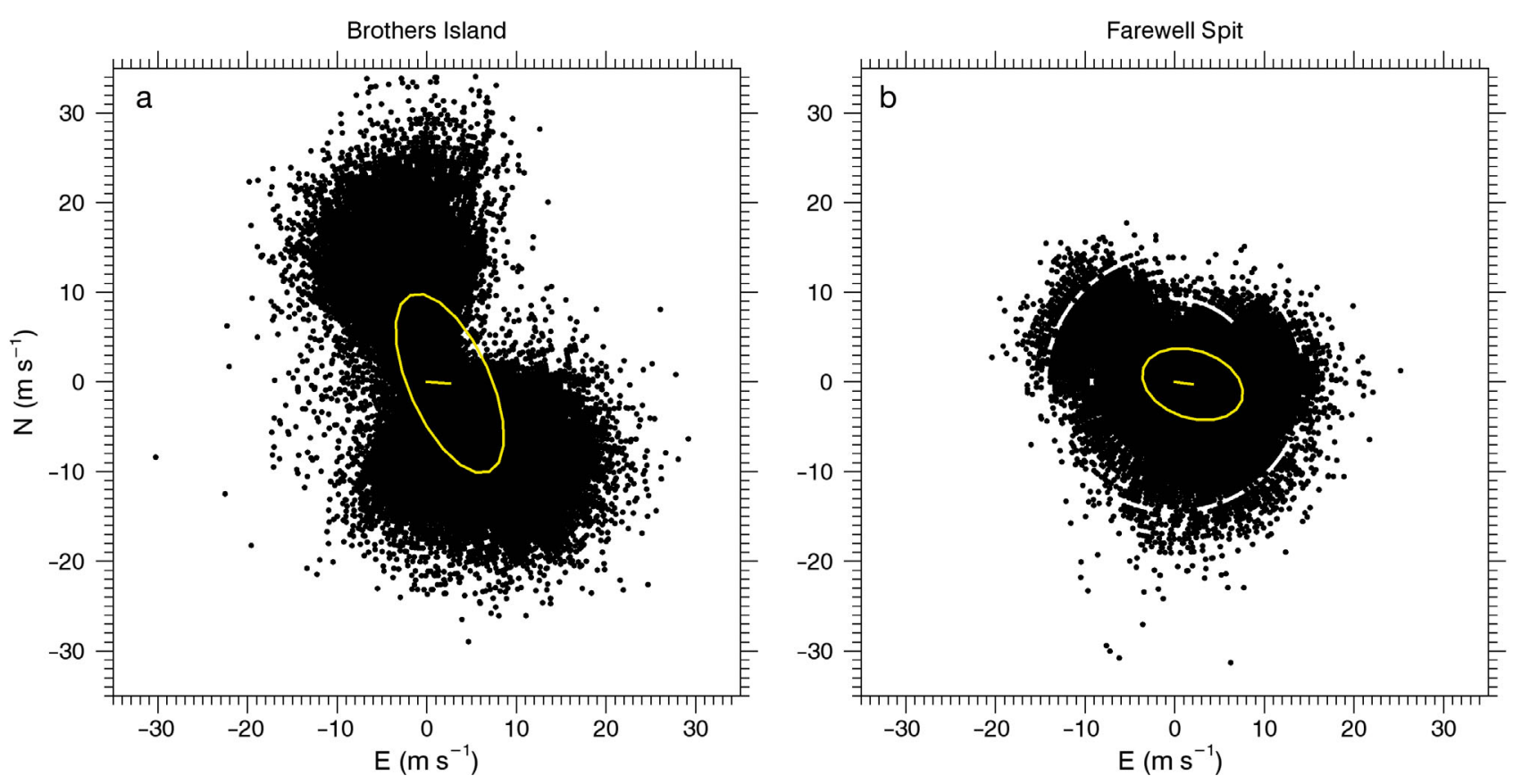

Fig. 4. Wind velocities (eastings, northings) for (a) Brothers Island from 1983 to 2009 and (b) Farewell Spit from 1986 to 2009. The yellow ellipse in each plot represents the variability in the vector data. A straight yellow line joins the centre of the ellipse (the mean value) with the origin. The major/minor axes of the ellipse represent the directions of largest/smallest variability

with SST (Fig. 5e) showed a zone of high correlation at Kahurangi Shoals. This zone trended into the western Cook Strait in a formation which intercepted the Pelorus Sound entrance area with correlation $\mathrm{r}=$ 0.35 to 0.40 (Fig. 5e, Table 4). This pattern was set against a background of lower correlation ( $r=0.25$ to 0.30 ) over the wider region, outside the upwelling zone. In winter (Fig. 5f), the SOI-SST correlation within the upwelling zone downstream of Kahurangi Shoals weakened significantly $(r=0.10)$, relative to its surrounding waters and also with respect to its summer value.

\section{DISCUSSION}

\section{Effectiveness of local and distal predictors of mussel yield and seston}

Zeldis et al. (2008) proposed that mussel yield in the largest mussel producing region in New Zealand (Pelorus Sound) could be predicted using environmental variables. Our present results confirmed this, but extended those findings to show that, perhaps unsurprisingly, the chemical and biological predictors collected locally to the mussel farming region within the sound were better predictors than physical predictors collected distally to the farming region. The local predictors are closely tied to the food sup- ply for bivalve aquaculture: diatom carbon and most significantly, PN, as an index of particulate organic matter, or seston. This indicated that investments in monitoring of local chemical and biological conditions could produce the most accurate predictive models of yield.

The regression modelling identified minimal adequate models which represented the best trade-off between degrees of freedom and fit of the model. For the local predictors, this was quite exclusive, with relatively few predictors found to optimise the fit. The modelling excluded chl $a$ and phytoplankton cell carbon but consistently optimised on PN, indicating its more consistent influence on mussel yield variation than the phytoplankton indices. This finding was likely due to the fact that PN (as an index of seston) in Pelorus Sound was composed of quite low proportions of living material $(\sim 16 \%$, indexed by phytoplankton cell carbon: Zeldis et al. 2008). Most suspended biomass was not in living cells, similar to Skidaway River Estuary, USA, where most suspended biomass was detrital (Verity 2002b). Zeldis et al. (2008) proposed that variable living:dead proportions and variable phytoplankton taxonomic proportions in the seston could have lowered the correlation of living cellular components of seston with mussel yield, while not greatly affecting the variability of seston overall. It was proposed that the combination of heterotrophic and autotrophic cycling within the 
a) SST vs. stress, Brothers Island, from SSE, summer

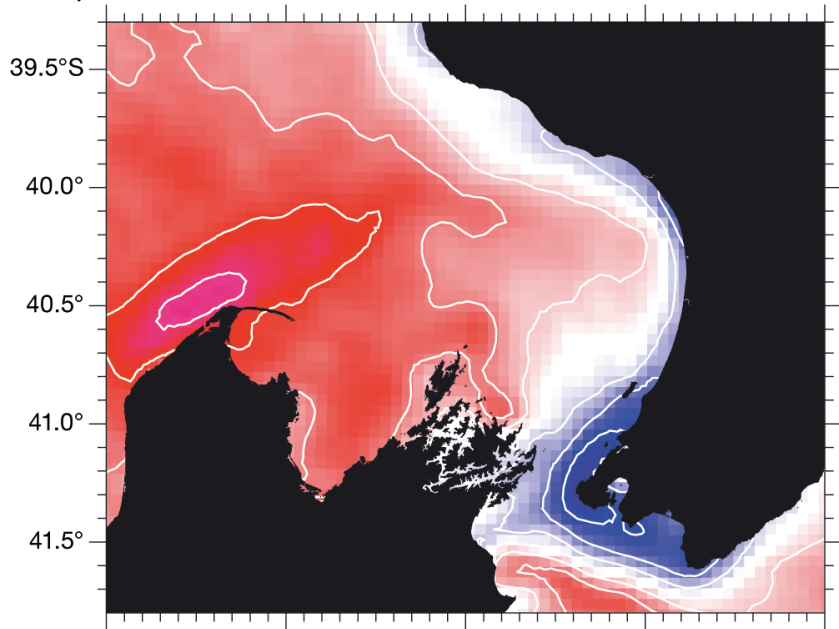

c) SST vs. stress, Farewell Spit, from E, summer

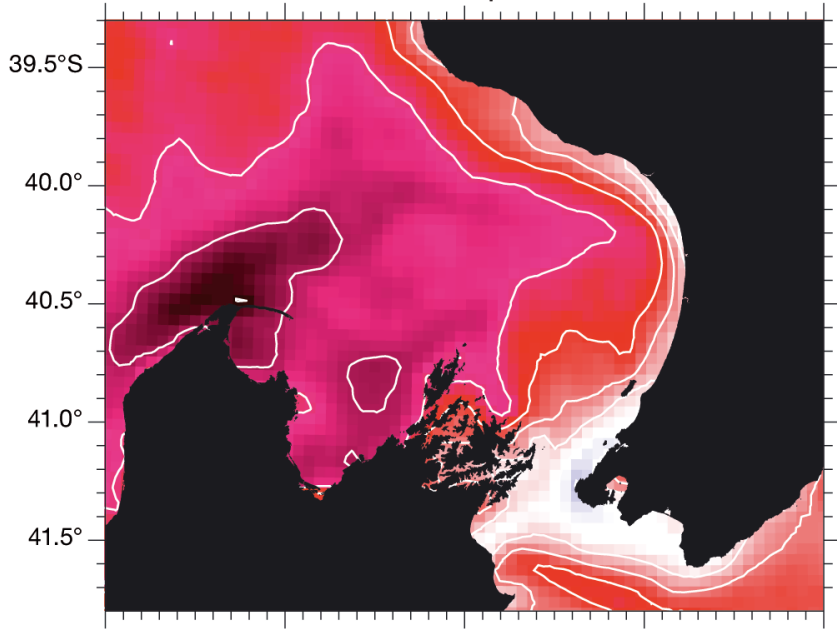

e)

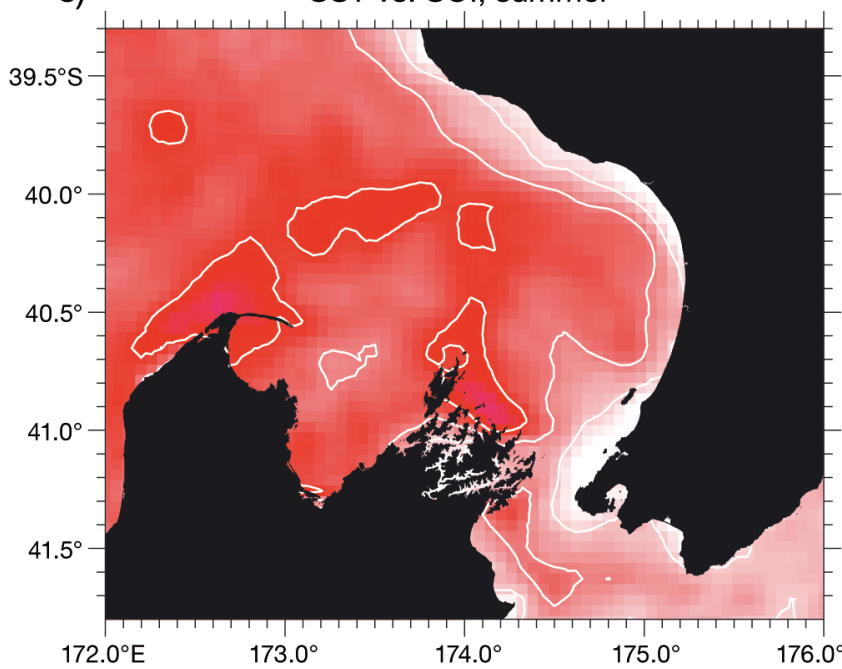

b) SST vs. stress, Brothers Island, from SSE, winter

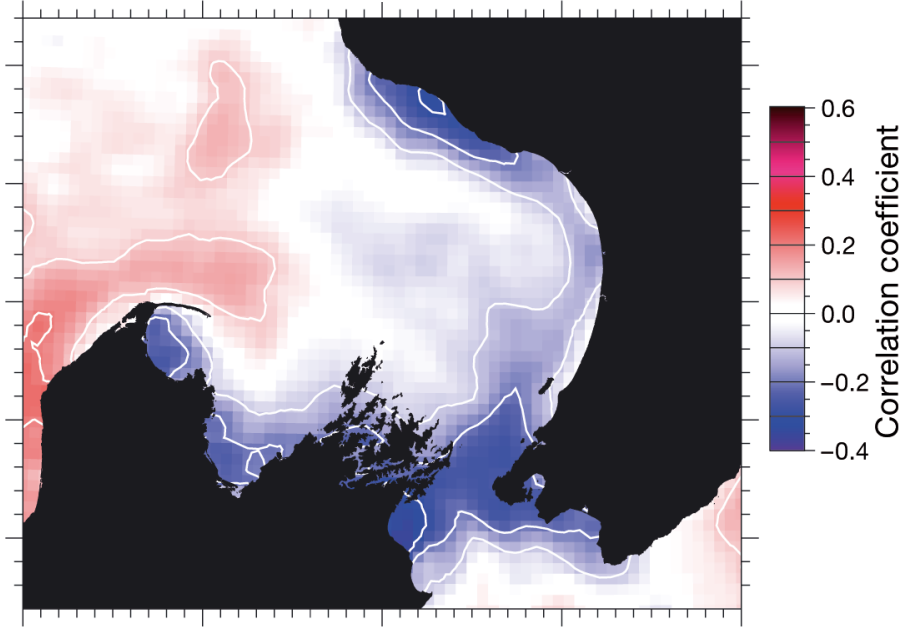

d) SST vs. stress, Farewell Spit, from E, winter

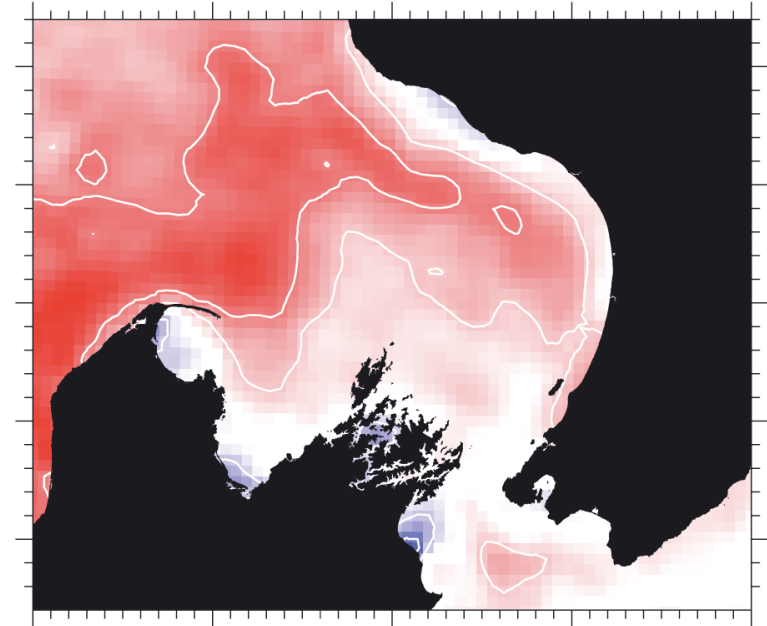

f)

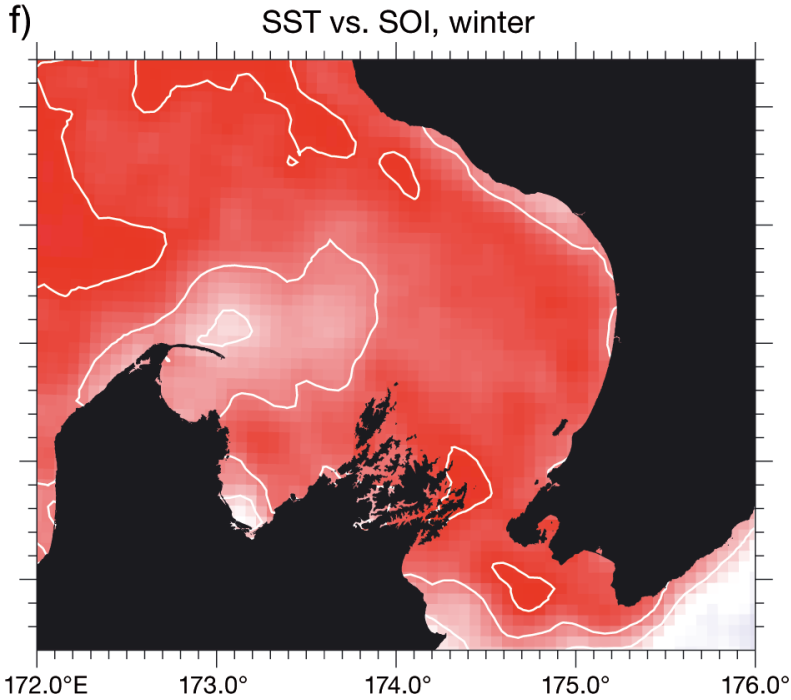

Fig. 5. (a,b) Spatial correlations of Cook Strait sea surface temperature (SST) and wind stress at Brothers Island in (a) summer and (b) winter half-years (positive stress is from SSE: $150^{\circ}$ ). (c,d) Spatial correlations between Cook Strait SST and wind stress measured at Farewell Spit in (c) summer and (d) winter half-years (positive stress is from E: $90^{\circ}$ ). These results show that in summer, winds with components from the E (W) correlate with warm (cold) waters, in the western Cook Strait. (e,f) Spatial correlations between Cook Strait SST and SOI in (e) summer and (f) winter half-years. These results show that in summer, La Niña conditions correlate with warm waters, and El Niño conditions correlate with cold waters, in western Cook Strait 
seston stabilises its variability, lessening short-term, 'boom-bust' cycles which characterise the living phytoplankton cell (autotrophic) components of estuarine plankton, a point also made by Boynton et al. (1982) and Verity (2002b).

Our regression models showed that mussel yield and $\mathrm{PN}$ were also predictable using only physical variables collected distally to the farming region (albeit with somewhat reduced precision relative to the local predictors). Similar to the local models, the distal models were also quite exclusive in the selection of predictors. For models of summer yield, this excluded SST (Table 2a), which, while significantly correlated with yield (Pearson product moment correlation $\mathrm{r}=$ 0.29 ; not shown), was less strongly correlated with yield than were SOI $(r=0.45)$ or wind stress $(r=0.47)$, which were included in the model. Correlation among these predictors (Table 4) may also have been a reason for exclusion of SST in this case.

The physical data represented by the distal predictors are routinely collected in New Zealand within national environmental monitoring programmes and databases. Unlike the collection of 'in water' chemical and biological samples, their collection does not incur expense and effort by individual stakeholders (in this case, aquaculture companies), yet we have shown that such data can be used to predict mussel aquaculture yield. Similar monitoring capabilities are available in other countries with bivalve aquaculture industries, suggesting that they could be similarly applied if relationships among physical drivers and aquaculture yield can be derived and understood mechanistically.

\section{Mechanisms of oceanic $\mathrm{NO}_{3}{ }^{-}$supply to Pelorus Sound entrance}

In the summer half-year, negative SOI, increased wind stress from the west, cooler SST and increased $\mathrm{NO}_{3}{ }^{-}$at $40 \mathrm{~m}$ depth in the Pelorus Sound entrance indicated that upwelling affected sound entrance waters. These physical conditions correlated with enhanced seston (PN) and mussel yield in summer, inside the sound. A mechanism for this is discussed here. Northwesterly winds at Brothers Island and westerly winds at Farewell Spit both correlated with cool SST off the sound entrance (Fig. 5a,c) in summer. The Farewell Spit wind station is close to Kahurangi Shoals, where westerly winds (blowing from $270^{\circ}$ toward $90^{\circ}$ ) are close to the ideal (along-shelf) direction favourable for upwelling (Bradford et al. 1986, Harris 1990, Shirtcliffe et al. 1990). There is evidence that the Kahurangi Shoals upwelling is the main source of SST variation at the Pelorus entrance, rather than upwelling more local to the Pelorus entrance. Water upwelled at Kahurangi Shoals is typically advected into the strait and driven southeast toward the Pelorus Sound entrance, under the prevailing west-to-east residual flow caused by the mean dynamic height difference through Cook Strait (Chiswell 2000). This was identified by Harris (1990) and described as an 'eddy street' which forms at Kahurangi Shoals and is swept eastward through the strait.

The coherent pattern in the summer SOI-SST correlation (Fig. 5e) also indicated upwelling at Kahurangi, reflecting the correlation of negative SOI and westerlies in summer in central New Zealand (Gordon 1986, Mullan 1998: see 'Environmental setting'). Bradford et al. (1986) showed that in summer, upwelling episodes at Kahurangi Shoals periodically injected $\mathrm{NO}_{3}{ }^{-}$-rich slope waters into the shelf water column, which had been depleted of $\mathrm{NO}_{3}{ }^{-}$by phytoplankton during the summer growth season. These enriched water masses drift eastward through Cook Strait and create horizontal $\mathrm{NO}_{3}{ }^{-}$maxima at the Pelorus Sound entrance, correlated with episodes of upwelling-favourable winds (Table 4).

In winter, relationships of westerlies and SST at the Pelorus Sound entrance were absent (Fig. 5b,d). At this time, the continental shelf water column in NW Cook Strait is nearly completely vertically mixed (Harris 1990), such that local upwelling-favourable winds exert little influence on surface water composition, including its heat content. However, we showed that SOI and SST were correlated in winter (Fig. 5f, Table 4). SOI is related to SST variation over the wider New Zealand Exclusive Economic Zone, thought to be driven during negative SOI by cooler southerlies, with net heat loss from the upper ocean (Mullan 1998), and with net heat gain during positive SOI, as warmer northeasterlies cover the region. Thus, in summer, the localised zone of higher correlation within and downstream of Kahurangi Shoals arose from upwelling, driven by SOI-correlated winds, which augmented the wide-area background cooling and warming from SOI-correlated air-sea exchange. In winter, the wide-area SOI-correlated air-sea exchange appeared to be the main source of SST variability.

The winter mixing of deep and surface shelf waters in Cook Strait minimises vertical variation in nutrient concentrations (Harris 1990, Gibbs et al. 1992), resulting in non-significant relationships of $\mathrm{NO}_{3}{ }^{-}$at the sound entrance with upwelling-favourable winds. In winter the only significant correlation for $\mathrm{NO}_{3}{ }^{-}$was 
with SST. Potential (albeit conjectural) mechanisms for this are that cool SST allows build-up of mixed layer $\mathrm{NO}_{3}{ }^{-}$, caused by slowed primary production and $\mathrm{NO}_{3}{ }^{-}$uptake (Eppley 1972, Bouman et al. 2005) or that increased winter southerlies cause deepened winter mixed layers and more $\mathrm{NO}_{3}{ }^{-}$entrainment. Irrespective, this winter oceanic $\mathrm{NO}_{3}{ }^{-}$variation did not correlate with winter variation in seston (PN) within the sound, unlike in summer.

\section{Forcing of seston biomass and mussel aquaculture yield within Pelorus Sound}

We next describe the oceanic and riverine forcing of seston concentration and mussel yield within the sound. The sampling at the sound entrance at $40 \mathrm{~m}$ depth detected 'new' $\mathrm{NO}_{3}{ }^{-}$available for estuarine transport into the sound (Gibbs et al. 1992) from Cook Strait. These $\mathrm{NO}_{3}{ }^{-}$anomalies were correlated with PN anomalies within the sound, but only in summer. No relationship was found between PN in the deep entrance waters with $\mathrm{PN}$ in the sound. Thus, it appeared that oceanic $\mathrm{NO}_{3}{ }^{-}$loading was underpinning $\mathrm{PN}$ formation within the sound, rather than direct PN loading from the ocean, in the summer half-year. These findings elucidated the mechanism driving the correlations between $\mathrm{PN}$ in the sound with upwelling-favourable winds and cool SST at the sound entrance found by Zeldis et al. (2008).

In the winter half-year, the numerous instances when the relation between $\mathrm{NO}_{3}{ }^{-}$at the sound entrance and $\mathrm{PN}$ within the sound strongly diverged and when PN instead correlated with river flow variation were strong evidence of the dominant effects of river flow on seston production in winter. This probably operated through the twin effects of freshwater inputs on nutrient supply and stratification, which alleviated co-limitation by nutrient and light levels (Mann \& Lazier 1991, Cloern 1999) by simultaneously adding riverine $\mathrm{NO}_{3}{ }^{-}$and maintaining cells in the upper water column (Gibbs \& Vant 1997). Although the multiple regression models identified river flow as a significant predictor of $\mathrm{PN}$ in both summer and winter, its influence in summer was unlikely to be as large as in winter, because $\mathrm{NO}_{3}{ }^{-}$loading rate was only about half that of winter.

It is primary production of organic matter which underlies PN formation in estuaries, fuelled by DIN supply and driven by combined autotrophic and heterotrophic cycling (Eppley et al. 1977, Verity 2002b). In Pelorus Sound over $9 \mathrm{yr}$ there was an approximately $40 \mathrm{mg} \mathrm{m}^{-3}$ range in $\mathrm{PN}$ concentration from a maximum in 1998 to a minimum from 2001 to 2003, followed by recovery (Fig. $2 \mathrm{~g}$ ), relative to an absolute mean concentration of PN of about $50 \mathrm{mg} \mathrm{m}^{-3}$ over that period (Zeldis et al. 2008). The sampling within the sound and at the sound entrance, combined with remotely sensed SST and hydrometric data, has provided plausible mechanisms for the findings of the regression modelling: that $\mathrm{NO}_{3}{ }^{-}$loading was underpinning $\mathrm{PN}$ formation within the sound, but that it was driven differently in summer (from Cook Strait) than in winter (from Pelorus River). Our regression modelling showed that the PN variation was strongly related to mussel yield in Pelorus Sound, as it is in other aquaculture regions (Figueiras et al. 2002, Strohmeier et al. 2005).

Previous studies have successfully modelled relationships of climatic variation and estuarine phytoplankton or seston biomass (e.g. Peterson et al. 1985, Lehman 1992, Verity 2002a, Møhlenberg et al. 2007), while other studies have demonstrated relationships between bivalve aquaculture yield and variation in its primary food supply (Armstrong 1982, Figueiras et al. 2002). However, in few cases have models of climatic drivers of phytoplankton or seston biomass been extended to consider the flow-on effects on yield of farmed bivalves. Figueiras et al. (2002) showed that upwelling/downwelling dynamics adjacent to the Galician Rías affected phytoplankton biomass and seston quality, which were shown by FernándezReiriez et al. (1996) to drive mussel growth rates. Blanton et al. (1987) had previously shown that upwelling indices (along-shelf winds) off Galicia were linked to mussel condition index, through the linkages with seston. This set of studies, along with ours in Pelorus Sound, are, to our knowledge, the only ones which have demonstrated linkages from climatic variation in physical forcing to formation of seston biomass, through to bivalve aquaculture yield.

\section{CONCLUSIONS}

With the addition of multiple regression modeling and new ocean and remote sensing time series, the present study has elucidated propositions made in earlier work (Zeldis et al. 2008) about forcing of Pelorus Sound bivalve aquaculture yield. It has described the ENSO teleconnection with mesoscale upwelling and its relationship with water mass composition and the nutrient supply to the Pelorus Sound entrance. The previously proposed summer-winter separation of nutrient drivers (oceanic in summer, riverine in winter) is robust: summer upwelling af- 
fects variation in the $\mathrm{NO}_{3}{ }^{-}$inventory at the sound entrance, but this relationship breaks down in winter; there is connectivity between the $\mathrm{NO}_{3}{ }^{-}$inventory at the sound entrance and seston (PN) concentration within the sound (but only in summer); and winter variations of seston concentration in the sound are explained by fluctuations in winter river flow. Overall, these results show that time series of biological, chemical and physical drivers can be useful for explaining nutrient loading and seston concentrations in estuaries and that ultimately they can explain variation in secondary production (Nixon \& Buckley 2002), in this case, of farmed bivalves. This outcome signifies the important role of climatic forcing in underpinning the food supply and yield of Pelorus Sound mussel aquaculture.

The multiple regression modelling showed that, while the best predictions included the locally collected chemical and biological information, it was also possible to make useful predictions solely from information contained in national databases of physical data, to explain why current growing conditions may be better or worse than average. This raises the potential for gaining information on lead time in terms of predicting growing conditions, and also on the potential longevity of good or bad conditions, once they take hold. Refinement of these predictions will depend on better understanding of periodicity in climatic patterns. Numeric ocean and estuarine models would be worthwhile objectives for future work, to further our understanding of underlying processes. Finally, further work incorporating new time series of mussel yield information is required to refine these predictions for the benefit of the Pelorus Sound mussel industry.

Acknowledgements. We thank the Marlborough Sounds Shellfish Quality Programme (MSQP) and Sealord Shellfisheries Ltd., who collected the marine and mussel-yield time series, respectively. We acknowledge the NIWA Remote Sensing, Climate and Hydrometric Centres for data, and the Cawthron Institute (NZ) analysed the phytoplankton samples. The work was funded by NIWA Core Fund ACEE1301.

\section{LITERATURE CITED}

Akaike H (1973) Information theory as an extension of the maximum likelihood principle. In: Petrov BN, Csaki F (eds) Proceedings of the Second International Symposium on Information Theory. Akademiai Kiado, Budapest, p 267-281

Álvarez-Salgado XA, Labarta U, Fernández-Reiriz MJ, Figueiras FG and others (2008) Renewal time and the impact of harmful algal blooms on the extensive mussel raft culture of the Iberian coastal upwelling system (SW
Europe). Harmful Algae 7:849-855

Armstrong NE (1982) Response of Texas estuaries to freshwater inflows. In: Kennedy VS (ed) Estuarine comparisons. Academic Press, New York, NY, p 103-120

Barbosa AB, Domingues RB, Galvão HM (2010) Environmental forcing of phytoplankton in a Mediterranean estuary (Guadiana Estuary, south-western Iberia): a decadal study of anthropogenic and climatic influences. Estuar Coasts 33:324-341

Blanton JO, Tenore KR, Castillejo F, Atkinson LP, Schwing FB, Lavin A (1987) The relationship of upwelling to mussel production on the rias of the western coast of Spain. J Mar Res 45:497-511

Bouman H, Platt T, Sathyendranath S, Stuart V (2005) Dependence of light-saturated photosynthesis on temperature and community structure. Deep-Sea Res I 52: 1284-1299

Boynton WR, Kemp WM, Keefe CW (1982) A comparative analysis of nutrients and other factors influencing estuarine phytoplankton production. In: Kennedy VS (ed) Estuarine comparisons. Academic Press, New York, NY, p 103-120

> Bradford JM, Lappenas PP, Murtagh RA, Chang FH, Wilkinson V (1986) Factors controlling summer phytoplankton production in greater Cook Strait, New Zealand. NZ J Mar Freshw Res 20:253-279

Bradford JM, Chang FH, Baldwin R, Chapman B, Downes M, Woods P (1987) Hydrology, plankton, and nutrients in Pelorus Sound, New Zealand, July 1981 and May 1982. NZ J Mar Freshw Res 21:223-233

Chang FH, Zeldis J, Gall M, Hall J (2003) Seasonal and spatial variation of phytoplankton assemblages, biomass and cell size from spring to summer across the northeastern New Zealand continental shelf. J Plankton Res 25:737-758

Chiswell SM (2000) The Wairarapa coastal current. NZ J Mar Freshw Res 34:303-315

Cloern JE (1999) The relative importance of light and nutrient limitation of phytoplankton growth: a simple index of coastal ecosystem sensitivity to nutrient enrichment. Aquat Ecol 33:3-15

> Cloern JE (2001) Our evolving conceptual model of the coastal eutrophication problem. Mar Ecol Prog Ser 210: 223-253

Crawley MJ (2002) Statistical computing: an introduction to data analysis using S-Plus. Wiley, Chichester

Dupra V (2000) Pelorus Sound New Zealand N and P budgets. LOICZ Biogeochemical Modelling Node. Available at http://nest.su.se/MNODE/New_Zealand/PelorusSound/ Pelorusbud.htm (accessed June 2013)

Efron B (1982) The jackknife, the bootstrap and other resampling plans. Society for Industrial and Applied Mathematics, Philadelphia, PA

Eppley RW (1972) Temperature and phytoplankton growth in the sea. Fish Bull 70:1063-1085

Eppley RW, Harrison WG, Chisholm SW, Stewart E (1977) Particulate organic material in surface waters off southern California and its relationship to phytoplankton. J Mar Res 35:671-696

Fernández-Reiriz MJ, Labarta U, Babarro JMF (1996) Comparative allometries in growth and chemical composition of mussel (Mytilus galloprovincialis lmk) culture in two zones in the Ría Sada (Galicia, NW Spain). J Shellfish Res 15(2):349-353

Figueiras FG, Labarta U, Fernández-Reiriz MJ (2002) Coastal upwelling, primary production and mussel 
growth in the Rías Baixas of Galicia. Hydrobiologia 484: 121-131

Friedland KD, Stock C, Drinkwater, KF, Link JS and others (2012) Pathways between primary production and fisheries yields of large marine ecosystems. PloS ONE 7: e28945

Gibbs MM, Vant WN (1997) Seasonal changes in factors controlling phytoplankton growth in Beatrix Bay, New Zealand. NZ J Mar Freshw Res 31:237-248

Gibbs MM, Pickmere SE, Woods PH, Payne GW, James MR (1992) Nutrient and chlorophyll a variability at six stations associated with mussel farming in Pelorus Sound, 1984-85. NZ J Mar Freshw Res 26:197-211

Gordon ND (1986) The southern oscillation and New Zealand weather. Mon Weather Rev 114:371-387

Harris TFW (1990) Greater Cook Strait-form and flow. New Zealand Oceanographic Institute, DSIR Marine and Freshwater, Wellington

Hayden B, Ross A, James M, Hadfield M, Gibbs M (2000) Carrying capacity: the way to sustainable shellfish production. Aquacult Update 25:7-9

> Heath RA (1976) Broad classification of New Zealand inlets with emphasis on residence times. NZ J Mar Freshw Res 10:429-444

> Huang CH, Lin HJ, Huang TC, Su HM, Hung JJ (2008) Responses of phytoplankton and periphyton to systemscale removal of oyster-culture racks from a eutrophic tropical lagoon. Mar Ecol Prog Ser 358:1-12

Kremer JN, Kemp WM, Giblin AE, Valiela I, Seitzinger SP, Hofmann EE (2000) Linking biogeochemical processes to higher trophic levels. In: Hobbie JE (ed) Estuarine science: a synthetic approach to research and practice. Island Press, Washington, DC, p 299-346

Lehman PW (1992) Environmental factors associated with long-term changes in chlorophyll concentration in the Sacramento-San Joaquin Delta and Suisan Bay, California. Estuaries 15:335-348

Mann KH, Lazier JRN (1991) Dynamics of marine ecosystems. Blackwell Scientific, Boston, MA

McKerchar AI (2002) Streamflow. In: Meyers, RA (ed) Encyclopedia of physical science and technology, 3rd edn, Vol 16. Academic Press, San Diego, CA, p 129-142

> McPhaden MJ, Zebiak SE, Glantz MH (2006) ENSO as an integrating concept in earth science. Science 314: 1740-1745

> Møhlenberg F, Petersen S, Petersen AH, Gameiro C (2007) Long-term trends and short-term variability of water quality in Skive Fjord, Denmark - nutrient load and mussels are the primary pressures and drivers that influence water quality. Environ Monit Assess 127:503-521

- Monbet Y (1992) Control of phytoplankton biomass in estuaries: a comparative analysis of microtidal and macrotidal estuaries. Estuaries 15:563-571

Mullan AB (1998) Southern hemisphere sea-surface temperatures and their contemporary and lag association with the New Zealand temperature and precipitation. Int J Climatol 18:817-840

> Nixon SW, Buckley BA (2002) 'A strikingly rich zone' nutrient enrichment and secondary production in coastal marine ecosystems. Estuaries 25:782-796

$>$ Ogilvie SC, Ross AH, Schiel DR (2000) Phytoplankton biomass associated with mussel farms in Beatrix Bay, New Zealand. Aquaculture 181:71-80
Peterson DH, Smith RE, Hager SW, Harmon DD, Herndon RE, Schemel LE (1985) Interannual variability in dissolved inorganic nutrients in northern San Francisco Bay estuary. Hydrobiologia 129:37-58

> Piñeiro G, Perelman S, Guerschman JP, Paruelo JM (2008) How to evaluate models: observed vs. predicted or predicted vs. observed? Ecol Model 216:316-322

Preisendorfer RW, Mobley CD (1988) Principal component analysis in meteorology and oceanography. Developments in Atmospheric Science 17. Elsevier, Amsterdam

Prins TC, Smaal AC, Dame RF (1998) A review of the feedbacks between bivalve grazing and ecosystem processes. Aquat Ecol 31:349-359

R Development Core Team (2012) R: a language and environment for statistical computing. R Foundation for Statistical Computing, Vienna. www.r-project.org

Ren JS, Ross AH (2005) Environmental influence on mussel growth: a dynamic energy budget model and its application to the greenshell mussel Perna canaliculus. Ecol Model 189:347-362

Safi KA, Gibbs MM (2003) Importance of different size classes of phytoplankton in Beatrix Bay, Marlborough Sounds, New Zealand, and the potential implications for the aquaculture of the mussel, Perna canaliculus. NZ J Mar Freshw Res 37:267-272

Sharples J, Greig MJN (1998) Tidal currents, mean flows, and upwelling on the north-east coast of New Zealand. NZ J Mar Freshw Res 32:215-231

Shearer JJ (1989) Pelorus Sound river water quality during low to medium flows. Marlborough District Council, New Zealand

> Shirtcliffe T, Moore MI, Cole AG, Viner AB, Baldwin R, Chapman B (1990) Dynamics of the Cape Farewell upwelling plume, New Zealand. NZ J Mar Freshw Res 24:555-568

> Strayer DL, Pace ML, Caraco NF, Cole JJ, Findlay SEG (2008) Hydrology and grazing jointly control a largeriver food web. Ecology 89:12-18

Strohmeier T, Aure J, Duinker A, Castberg T, Svardal A, Strand $\varnothing$ (2005) Flow reduction, seston depletion, meat content and distribution of diarrhetic shellfish toxins in a long-line blue mussel (Mytilus edulis) farm. J Shellfish Res 24:15-23

Uddstrom MJ, Oien NA (1999) On the use of high-resolution satellite data to describe the spatial and temporal variability of sea surface temperatures in the New Zealand region. J Geophys Res 104:20729-20751

Venables WN, Ripley BD (2002) Modern applied statistics with S, 4th edn. Springer, New York, NY

- Verity PG (2002a) A decade of change in the Skidaway River estuary I. Hydrography and nutrients. Estuaries 25: 944-960

> Verity PG (2002b) A decade of change in the Skidaway River estuary II. Particulate organic carbon, nitrogen and chlorophyll a. Estuaries 25:961-975

Zeldis J, Robinson K, Ross A, Hayden B (2004) First observations of predation by New Zealand greenshell mussels (Perna canaliculus) on zooplankton. J Exp Mar Biol Ecol 311:287-299

> Zeldis JR, Howard-Williams C, Carter CM, Schiel DR (2008) ENSO and riverine control of nutrient loading, phytoplankton biomass and mussel aquaculture yield in Pelorus Sound, New Zealand. Mar Ecol Prog Ser 371:131-142

Submitted: June 15, 2011; Accepted: March 25, 2013

Proofs received from author(s): May 21, 2013 